\title{
PERLINDUNGAN HUKUM TERHADAP MASYARAKAT HUKUM ADAT DI INDONESIA ATAS PEMANFAATAN SUMBER DAYA GENETIK SEBAGAI SUATU KEKAYAAN INTELEKTUAL
}

\author{
Ghandis Clarinda Tiara Hanum ${ }^{1}$, Budi Santoso ${ }^{2}$
}

\begin{abstract}
Abstrak
Masyarakat hukum adat sangat berperan penting dalam mengungkap manfaatmanfaat sumber daya genetik tertentu. Namun ironisnya, tidak sepeser pun keuntungan yang diperoleh oleh masyarakat hukum adat di Indonesia sementara negara-negara maju melalui rezim HKI memperoleh banyak keuntungan dari pemanfaatan sumber daya genetik yang berasal dari pengetahuan masyarakat hukum adat. Penelitian ini dilakukan untuk mengkaji: apakah Rezim HKI mampu mengakomodasi perlindungan hukum terhadap masyarakat hukum adat atas pemanfaatan sumber daya genetik sebagai kekayaan intelektual? Bagaimana kebijakan perlindungan hukum terhadap masyarakat hukum adat atas pemanfaatan sumber daya genetik sebagai kekayaan intelektual di Indonesia pada saat ini dan masa mendatang? Metode pendekatan yang digunakan adalah yuridis normatif. Kesimpulan yang diperoleh dari penelitian ini adalah bahwa Rezim HKI tidak mampu mengakomodasi perlindungan hukum terhadap masyarakat hukum adat atas pemanfaatan sumber daya genetik Kebijakan di Indonesia saat ini masih berpedoman pada sistem pengakuan bersyarat masyarakat hukum adat.
\end{abstract}

Kata Kunci: Perlindungan Hukum, Masyarakat Hukum Adat, Sumber Daya Genetik

${ }^{1}$ Mahasiswa Program Studi Magister IImu Hukum UNDIP

${ }^{2}$ Dosen Program Studi Magister IImu Hukum UNDIP 


\begin{abstract}
Masyarakat hukum adat play an important role in revealing particular genetic resources benefits. Ironically, masyarakat hukum adat in Indonesia does not get any benefit from it. Meanwhile, developed countries use frequently use the regime of Intellectual Property Right (IPR) to get monopoly right for the genetic resourcesbased product originated from the their knowledge. The problem are : Can the regime of IPR accomodate law protection of masyarakat hukum adat for the use of genetic resources as intellectual property? How is the policy of law protection of masyarakat hukum adat for the use of genetic resources as intellectual property in Indonesia in the future? The approach method in this research was normative juridical method. The research conclusion is that IPR Regime can't accomodate law protection of masyarakat hukum adat for the use of genetic resources. The policy in Indonesia today is still based on the condition recognition system of masyarakat hukum adat.
\end{abstract}

Keywords: Law Protection, Masyarakat Hukum Adat, Genetic Resources. 


\section{A. Latar Belakang}

$$
\begin{aligned}
& \text { Penemuan rekombinasi } \\
& \text { DNA di tahun } 1953 \text { yang diikuti } \\
& \text { dengan perkembangan } \\
& \text { bioteknologi serta ilmu } \\
& \text { pengetahuan dan sains } \\
& \text { menyebabkan kebutuhan akan } \\
& \text { sumber daya genetik yang berasal } \\
& \text { dari tanaman, hewan, } \\
& \text { mikroorganisme, dan manusia } \\
& \text { meningkat pesat untuk digunakan } \\
& \text { sebagai bahan baku berharga } \\
& \text { (valuable raw materials) dalam } \\
& \text { berbagai sektor ekonomi. }{ }^{3} \text { Industri } \\
& \text { bioteknologi yang bersumber dari } \\
& \text { sumber daya genetik sejauh ini } \\
& \text { banyak terkonsentrasi di negara- } \\
& \text { negara maju. Sementara itu, } \\
& \text { negara-negara berkembang kalah }
\end{aligned}
$$

3 Ten Kate dan Laird dalam Sebastian Oberthur, dkk, 2011, Study Intellectual Property Rights on Genetic Resources and The Fight Against Poverty, Belgia, Eurepean Parliament, hlm. 9, <http://www.ecologic.eu/files/attachments/Project s/2610/2610_20_ipr_study_final.pdf>, diakses pada 1 Oktober 2012 berkembang dalam industri

bioteknologinya tetapi merekalah

yang berperan penting sebagai

'penyedia' sumber daya genetik

bagi industri bioteknologi di

negara-negara maju. Hal tersebut

dikarenakan hutan tropis yang kaya

akan keanekaragaman hayati

banyak tersebar di wilayah

geografis negara-negara

berkembang. ${ }^{4}$

Perkembangan industri

bioteknologi dan komersialisasi

${ }^{4}$ Hutan tropis secara geografis merupakan hutan yang terletak di antara 20 derajat Lintang Selatan dan garis 20 derajat Lintang Utara. Di antara kedua Garis Lintang itu membentang hutan tropis yatiu yang berada di Amerika Selatan, Amerika Tengah, Asia Tenggara, dan Asia Timur (yang rata-rata merupakan wilayah negara berkembang berada). Keanekaragaman hayati dalam hutan tropis berkaitan dengan kerumitan ekologinya yang melampaui jumlah yang terdapat dalam kawasan hutan lain dengan luas yang sama. Kerumitan ekologi dalam hutan tropis berasal dari cahaya, kehangatan, dan kelembaban yang luar biasa banyaknya, yang terus menerus menciptakan lingkungan yang menguntungkan bagi evolusi sumber daya hayati. (Lihat Otto Soemarwoto dan I Nyoman Myers dalam FX Adji Samekto, Keberpihakan Konvensi Keanekaragaman Hayati pada Kepentingan Negara Maju, (Majalah Masalah-Masalah FH Univesitas Diponegoro, Vol. 35 No. 2 April-Juni 2006), hlm 138-139 
produk-produk berbasis sumber

daya genetik tersebut mendapat

perhatian khusus dalam tataran

internasional, yakni dengan

lahirnya Convention on Biological

Diversity

(CBD)/Konvensi

Keanekaragaman Hayati pada

tahun 1992. Penekanan CBD pada

bioteknologi ini didasari bahwa

bioteknologi telah 'berjasa'

meningkatkan nilai sumber daya

genetik $^{5}$ dan hal ini menimbulkan

keresahan di kalangan negara-

negara berkembang. ${ }^{6} \quad$ Negara-

negara berkembang merasa

5 Ibid, hlm 20.

6 Negara-negara berkembang (developing countries) adalah mengacu kepada negaranegara yang tidak saja memiliki pendapatan perkapita yang rendah, tetapi juga masih menghadapi masalah-masalah sosial seperti buta huruf, angka kematian bayi, problem kekurangan gizi dan ketertinggalan dalam bidang teknologi (Ibid.). Di samping itu, Istilah negara berkembang ini juga bisa menunjuk kepada beberapa negara bekas daerah jajahan yang menuju kemerdekaan pada tahun 1950-an, yang oleh Presiden Truman dari Amerika Serikat disebut sebagai "negara terbelakang. (Lihat: Johannes Muller, 2006, Perkembangan Masyarakat Lintas IImu, Jakarta, PT. Gramedia Pustaka Utama, hlm. 10. dirugikan karena mereka telah

‘mendonasikan' sumber daya

genetik mereka hanya untuk

membeli kembali sumber daya genetik tersebut dari perusahaan multinasional di negara-negara maju. ${ }^{7}$ Negara-negara maju dan negara-negara berkembang seharusnya dapat memanfaatkan situasi tersebut sebagai sebuah simbiosis mutualisme. Akan tetapi, faktanya negara-negara maju melalui Rezim HKI seringkali memanfaatkan persyaratan patentability sebagai senjata utama mereka untuk memperoleh paten atas produk yang berbasis sumber daya genetik yang berasal dari negara-negara berkembang dan mengeruk keuntungan melalui royalti. Tindakan negara-negara

${ }^{7}$ Loc. Cit. 
maju tersebut diistilahkan dengan misappropriation. $^{8}$

Salah satu kasus

missapropriation yang dialami

Bangsa Indonesia adalah

Permohonan Paten

Immunostimulating

Polysaccharides Isolated From

Curcuma xanthorrhiza and

Manufacturing Method Thereof

oleh Inventor dari Korea Selatan;

Jae-Kwan Hwang, Ah-Jin Kim,

Jong-Hee Sohn, Kyu-Lee Han,

Sun-Hee Lee, Jeong-Han Choo

terhadap US Patent Office dengan

US Patent Application No.

20100048885 pada tahun 2010.

Polysaccharides dari Curcuma

${ }^{8}$ Misappropriation diartikan sebagai penggunaan tanpa hak atau melawan hukum dengan mengabaikan hak-hak masyarakat lokal atas TK dan sumber hayati yang terkait, yang menjadi milik masyarakat yang bersangkutan. Pengertian ini diambil dari Black's Law, yaitu misappropriation is the unauthorized, improprer or unlawful use of funds or property for purpose other than that for which intended. xanthorrhiza ini telah terbukti efektif untuk membunuh sel kanker. ${ }^{9}$ Curcuma xanthorrhiza adalah nama latin dari temulawak yang merupakan tanaman asli Indonesia dan telah dikenal lama sebagai obat tradisional. Kasus tersebut membuktikan bahwa produk-produk berbasis sumber daya genetik hampir selalu 'tercipta' berkat 'pengungkapan' masyarakat asli atas manfaatmanfaat sumber daya genetik tertentu. Masyarakat asli itu sendiri merupakan terminologi yang tidak dikenal dalam sistem hukum Indonesia karena pemerintah Indonesia lebih memilih menggunakan istilah masyarakat hukum adat. Masyarakat hukum 9 <Tanpa Nama>, <Tanpa Judul>,
<http://www.faqs.org/patents/app/20100048885\#ixz
z2NPY70zLH>. 
adat terhadap tumbuh-tumbuhan

dan hewan di dalam wilayahnya

adalah bentuk ketergantungan

masyarakat hukum adat terhadap

sumber daya genetik. Hal ini

merupakan titik temu dari urgensi

perlindungan hukum terhadap

masyarakat hukum adat atas

pemanfaatan sumber daya genetik

yakni berupa suatu perlindungan

terhadap hak ulayatnya sekaligus

merupakan perlindungan terhadap

hak hidupnya.

Berdasarkan latar belakang

tersebut, maka dapat dirumuskan

permasalahan, antara lain:

pertama, apakah rezim hak

kekayaan intelektual dapat

mengakomodasi perlindungan

hukum terhadap masyarakat

hukum adat ketika sumber daya

genetik dimanfaatkan sebagai

suatu kekayaan intelektual? Kedua, bagaimana kebijakan perlindungan

hukum terhadap masyarakat

hukum adat atas pemanfaatan

sumber daya genetik sebagai

kekayaan intelektual di Indonesia

pada saat ini dan masa yang akan

datang?

\section{B. Metode Penelitian}

Metode pendekatan yang

digunakan oleh penulis dalam

penelitian adalah pendekatan

yuridis normatif. Metode

pendekatan yuridis normatif

biasanya "hanya" merupakan studi

dokumen, yakni menggunakan

sumber-sumber data sekunder saja

yang berupa peraturan perundang-

undangan, keputusan pengadilan,

teori hukum, dan pendapat

parasarjana. Itu pula sebabnya

digunakan analisis secara kualitatif

(normatif-kualitatif) karena 
datanya bersifat kualitatif. $^{10}$

Penelitian hukum normatif ini

menggunakan

beberapa

pendekatan, antara lain pendekatan

perundang-undangan, pendekatan

konsep, pendekatan perbandingan,

dan pendekatan historis/sejarah.

\section{Kerangka Teori}

Permasalahan pertama akan

dikaji berdasarkan teori hukum

alam dari Thomas Aquinas.

Thomas Aquinas melihat kodrat

manusia bersifat teleologis, yaitu

memiiki kecenderungan yang

terarah pada tujuan tertentu. Apa

yang dituju itu atau apa yang

menjadi orientasi kodrat manusia

itu adalah 'baik' atau 'kebaikan'. ${ }^{11}$

Selain itu, juga akan dianalisis

dengan teori dari Jeremy Betham.

10

Soerjono Soekanto dan Sri Mamudji, 2010, Penelitian Hukum Normatif Suatu Tinjauan Singkat, Jakarta, PT Raja Grafindo Persada, hlm 24.

11 Loc. Cit.
Hukum harus diciptakan

berdasarkan rasa keadilan

masyarakat demi kebahagiaan

warga masyarakat yang

bersangkutan. Ukuran rasional

yang objektif dari kemanfaatan

tersebut adalah jika hukum yang

dimaksud secara ekonomis mampu

menciptakan kesejahteraan bagi

sebagian terbesar warga

masyarakatnya. $^{12}$

Permasalahan kedua akan

dianalisis dengan menggunakan

teori Positivisme Hukum. Esensi

positivisme melihat hukum sebagai

sistem perundang-undangan yang

dibuat dan diberlakukan oleh

negara secara formal (hukum

positif). Walaupun sebuah nilai

mempunyai kekuatan mengikat

dan dipatuhi oleh orang banyak

12 Jeremy Bentham dalam Agus Sardjono, 2006, Hak Kekayaan Intelektual dan Pengetahuan Tradisional. Bandung: PT. Alumni, hlm 32-33. 
seperti ajaran moral atau ajaran agama, tetapi tidak bisa dikatakan sebagai sebuah hukum kalau ia tidak dirumuskan dalam peraturan yang dibuat oleh negara. ${ }^{13}$ Sementara itu, untuk memprediksi bagaimana kebijakan perlindungan hukum terhadap masyarakat hukum adat atas pemanfaatan sumber daya genetik sebagai kekayaan intelektual di Indonesia di masa mendatang akan dimulai dengan menggunakan Teori David Hume. Hume merancang sebuah model keadilan yang bertumpu pada keterjaminan pemilikan yang wajar. Artinya: (i) pemilikan barang tidak boleh berlebihan, (ii) pemilikan tersebut harus diperoleh secara halal, dan Dualisme Penelitian Hukum Normatif dan Empiris, Yogyakarta, Pustaka Pelajar, hlm. 12 pemindahannya harus berdasarkan kesepakatan serta menepati janji. ${ }^{14}$ Permasalahan kedua akan dianalisis pula dengan menggunakan teori Roscoe Pound. Pound sangat menekankan pada efektifitas bekerjanya hukum dan sangat mementingkan pada beroperasinya hukum di dalam masyarakat. ${ }^{15}$ Selain itu, Pound berpendapat bahwa hukum berfungsi sebagai sarana pembaruan, di samping sarana untuk menjamin ketertiban dan kepastian hukum. ${ }^{16}$

\section{Hasil dan Pembahasan}

\section{Rezim Hak Kekayaan}

\section{Intelektual Tidak Mampu}

\footnotetext{
${ }^{14}$ Ibid, hlm 89.

15 Otje Salman \& Anton F. Susanto, 2004, Beberapa Aspek Sosiologi Hukum, Bandung, PT. Alumni, hlm. 35.

${ }^{16}$ Khudzaifah Dimyati, 2004, Teorisasi Hukum : Studi tentang Perkembangan Pemikiran Hukum di Indonesia 1945-1990, Surakarta, Muhammadiyah, hlm 29
} 
Mengakomodasi

Perlindungan

Hukum

terhadap Hak Masyarakat

Hukum Adat atas

Pemanfaatan Sumber Daya

Genetik sebagai Kekayaan

Intelektual

a. Konsep Intellectual

Creation yang Dilindungi

dalam Rezim Hak

Kekayaan Intelektual

Berbeda dengan

Masyarakat Hukum Adat.
Faktanya, kriteria-kriteria

intellectual creation yang dapat dilindungi oleh rezim

HKI sangat berbeda dengan

kriteria-kriteria intellectual

creation yang hidup dalam

masyarakat adat atau pun

masyarakat hukum adat di

Indonesia, berikut

perbedaannya: 


\begin{tabular}{|c|c|c|c|}
\hline No. & $\begin{array}{l}\text { Perbedaan Konsep } \\
\text { Intellectual } \\
\text { Creation }\end{array}$ & $\begin{array}{c}\text { Hak Kekayaan } \\
\text { Intelektual } \\
\text { (HKI) }\end{array}$ & $\begin{array}{c}\text { Masyarakat Adat/Masyarakat } \\
\text { Hukum Adat di Indonesia }\end{array}$ \\
\hline 1. & $\begin{array}{l}\text { Kriteria } \\
\text { Kepemilikan }\end{array}$ & $\begin{array}{l}\text { Individual } \\
\rightarrow \text { pengaruh dari } \\
\quad \text { filsafat } \\
\text { individualisme dan } \\
\text { kapitalisme. }\end{array}$ & $\begin{array}{l}\text { Komunal atau Kolektif } \\
\rightarrow \text { pengaruh dari kearifan } \\
\text { lokal masyarakat adat salah } \\
\text { satunya adalah konsep'gotong } \\
\text { royong'. }\end{array}$ \\
\hline 2. & $\begin{array}{l}\text { Kriteria tentang } \\
\text { Standar } \\
\text { Kreasi Intelektual }\end{array}$ & $\begin{array}{l}\text { Ekspresi Kemampuan } \\
\text { Berpikir Manusia } \\
\text { Baru } \\
\text { dan/atau Orisinil }\end{array}$ & $\begin{array}{l}\text { Tradisi yang Diturunkan dari } \\
\text { Satu Generasi ke Generasi } \\
\text { Lain. }\end{array}$ \\
\hline 3. & $\begin{array}{l}\text { Kriteria } \\
\text { Dokumentasi }\end{array}$ & $\begin{array}{l}\text { Tertulis sesuai dengan } \\
\text { format yang telah } \\
\text { ditentukan }\end{array}$ & $\begin{array}{l}\text { Tidak tertulis yang dapat } \\
\text { berupa tradisi lisan dan } \\
\text { kitabkitab } \\
\text { pengobatan kuno }\end{array}$ \\
\hline 4. & $\begin{array}{l}\text { Kriteria } \\
\text { Kepentingan yang } \\
\text { Dilindungi }\end{array}$ & $\begin{array}{l}\text { Nilai ekonomi/bersifat } \\
\text { komersial }\end{array}$ & $\begin{array}{l}\text { - Tidak dikenal tentang nilai } \\
\text { ekonomi atau komersial } \\
\text { - Terkadang memiliki nilai } \\
\text { kesakralan dan dianggap suci }\end{array}$ \\
\hline
\end{tabular}

Sumber : Hasil dari berbagai sumber yang diolah oleh Penulis 
b. Sumber Daya Genetik merupakan Warisan

Bersama Umat Manusia

Pengertian sumber

daya genetik berdasarkan

Convention on Biological

Diversity tidak digunakan

secara umum sebagai suatu

konsep hukum dan tidak

pula merepresentasikannya

secara jelas sebagai objek

hak milik. ${ }^{17}$ Annie O. Wu

berpendapat bahwa prinsip

yang digunakan oleh para

prospectors dalam rangka

memanfaatkan sumber daya

hayati adalah 'Common

Heritage of Humankind'

atau warisan bersama umat

manusia. Berdasarkan

prinsip ini, setiap orang

17 Peter Johan Schei dan Morten Walloe Tvedt, Genetic Resources in the CBD : the Wording, the Past, the Present, and the Future, hIm 6. mempunyai hak yang sama

untuk memanfaatkan

sumber daya alam,

termasuk sumber daya

hayati, yang tersedia di

muka bumi. Pembatasan

yang ada dalam

pemanfaatan hanyalah

kedaulatan negara dimana

sumber daya tersebut

berada. Hal ini telah diakui

pula di dalam CBD. Oleh

karena itu, pendekatan yang

dilakukan negara maju

menyangkut akses terhadap

sumber daya genetik adalah

melalui penawaran imbalan

berupa pembagian

keuntungan (benefit

sharing). ${ }^{18}$

Common Heritage

of Humankind adalah

${ }^{18}$ Agus Sardjono, Op.Cit., hlm 77. 
konsep yang tidak dikenal

dalam Rezim HKI sehingga

tidak mungkin dpat

diajukan Paten, Hak Cipta,

dan sebagainya.

Perlindungan yang dapat

diberikan Rezim HKI

adalah semua bentuk

intellectual creation yang

berasal dari sumber daya

genetik sebagai common

heritage of humankind

tersebut selama memenuhi

kriteria dari Rezim HKI.

Namun konsekuensinya,

negara-negara berkembang

dan masyarakat hukum

adatnya yang merupakan

provider dari sumber daya

genetik kelak harus

membayar untuk produk

yang sesungguhnya berasal

dari 'mereka' dan tanpa mendapat

kompensasi

sedikit pun. Pada tahap

inilah ketidakadilan muncul

dan rezim HKI tidak

mampu menyelesaikan

problematika ini.

2. Kebijakan Perlindungan Hukum

terhadap Masyarakat Hukum

Adat atas Pemanfaatan Sumber

Daya Genetik di Indonesia

a. Kebijakan Perlindungan

Hukum terhadap Masyarakat

Hukum Adat di Indonesia atas

Pemanfaatan Sumber Daya

Genetik di Masa Kini

1) Pengakuan Bersyarat

terhadap Masyarakat

Hukum Adat di Indonesia

Pemerintah

Indonesia pada dasarnya

memberlakukan pengakuan

bersyarat supaya suatu

kelompok masyarakat adat 


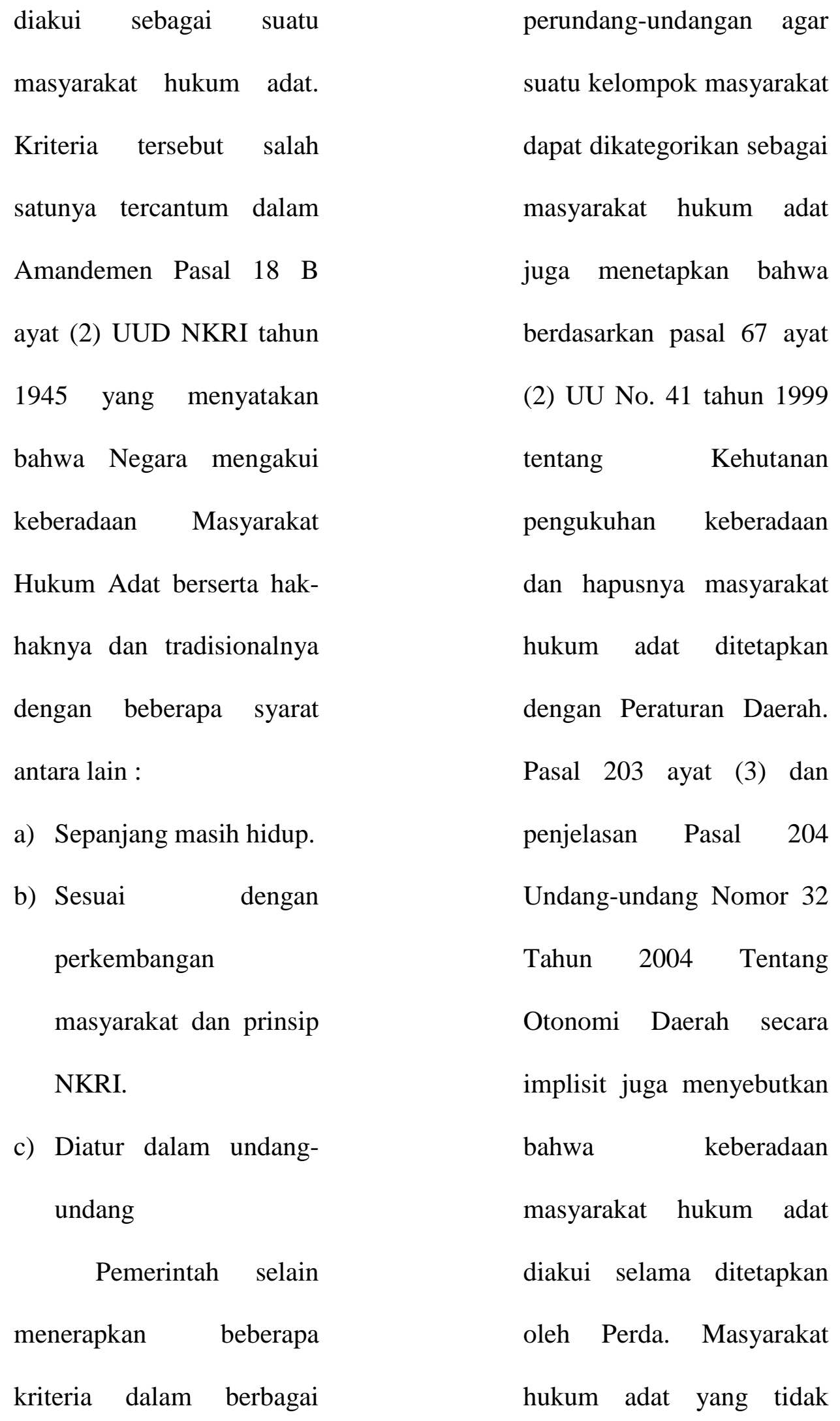


ditetapkan dalam Perda
maka hanya akan berstatus
sebagai masyarakat hukum
adat secara sosial dan tidak
memiliki kedudukan secara

hukum. $^{19}$

Rikardo Simarmata

dalam

penelitiannya

tentang Pengakuan Hukum

terhadap Masyarakat Adat

di Indonesia selama tahun

2005-2006, wilayah yang

telah mengakui secara tegas

tentang keberadaan

masyarakat hukum adat dan

hak ulayatnya, yaitu: ${ }^{20}$

19

Saafroedin Bahar, Komisioner Masyarakat Hukum Adat KOMNAS HAM, dalam diskusi Perlindungan Negara Terhadap Hak Konstitusional Masyarakat Hukum Adat di Jakarta 2 Agustus 2006, $<$ http://www.hukumonline.com/berita/baca/hol152 57/berdayakanmasyarakat-hukum-adat-untukperlindungan-lingkungan>, diakses pada 1 Oktober 2012.

20 Rikardo Simarmata, 2006, Pengakuan Hukum Terhadap Masyarakat Adat di Indonesia, Bangkok, UNDP, hlm 209 dan hlm 253-258. Perda tentang Masyarakat Hukum Adat Baduy dan Masyarakat Hukum Adat Dayak Lunayeh
1) Perda Kabupaten Lebak

Propinsi Banten No. 32

tahun 2001 tentang

Perlindungan atas Hak

Ulayat Masyarakat

Baduy.

2) Perda Kabupaten

Nunukan Propinsi

Kalimantan Timur No.

3 tahun 2004 tentang

Hak Ulayat Masyarakat

Hukum Adat.

3) Perda No. 4 tahun 2004

tentang Hak Ulayat

Masyarakat Hukum

Adat

(Dayak)

Lundayeh.

4) Perda Kabupaten

Bungo Propinsi Jambi

No. 3 tahun 2006 juga diungkapkan Maria Soemardjono, 2009, Tanah dalam Perspektif Hak Ekonomi, Sosial, dan Budaya, Jakarta, Kompas Gramedia, hlm. 167. 
tentang Masyarakat

Hukum Adat Datuk

Sinaro Putih Kecamatan

Pelepat Kabupaten

Bungo.

2) Hak Masyarakat Hukum Adat atas Sumber Daya Genetik

Hak masyarakat
adat atas sumber daya
genetik diawali dari
pengakuan atas hak ulayat
masyarakat hukum adat.
Hak ulayat secara umum
berkenaan dengan
hubungan hukum antara
masyarakat hukum adat
dengan tanah dalam
wilayahnya. Hubungan
hukum tersebut berisi
wewenang dan kewajiban.
Dalam pengertian tanah
dalam angan

wilayahnya' itu mencakup

luas kewenangan

masyarakat hukum adat

berkenaan dengan tanah

termasuk segala isinya,

yakni perairan,

tumbuhtumbuhan, dan

binatang dalam wilayahnya

yang menjadi sumber

kehidupan dan mata

pencahariannya. $^{21}$

Hak ulayat

sebagaimana telah

dijelaskan di atas adalah

hak atas tanah, perairan,

tumbuhtumbuhan, dan

binatang yang ada dalam

wilayah hidupnya dan yang

menjadi sumber

penghidupannya. Hal ini

memiliki benang merah

${ }^{21}$ Ter Haar dalam Maria Sumardjono, Op.Cit., hlm. 170. 
bila dikaitkan dengan
pengertian sumber daya
genetik dalam Convention
On Biological Diversity/
CBD yakni :

Article 2 CBD:

“Genetic resources

means genetic material

of actual or potential

value." (sumber daya

genetik adalah material

genetik yang

mempunyai nilai nyata

atau potensial).

"Material genetic

means any material of

plant, animal,

microbial, or other

origin containing

functional units of

heredity" (material

genetik adalah bahan

dari tumbuhan, binatang, jasad renik

atau jasad lain yang

mengandung unit-unit

fungsional pewarisan

sifat (hereditas)).

Berdasarkan pada pengertian dari sumber daya genetik tersebut maka dapat disimpulkan bahwa hak ulayat meliputi pula hak masyarakat hukum adat atas sumber daya genetik yang ada dalam wilayah hidupnya dan yang menjadi sumber penghidupannya. Oleh karena itu, masyarakat hukum adat di Indonesia pada hakikatnya telah memperoleh pengakuan hukum dan perlindungan hukum (melalui pengakuan hak ulayat) sebagai pemangku hak atas sumber 
daya genetik yang ada di wilayah hidupnya dan yang menjadi sumber penghidupannya. Namun, pengakuan dan perlindungan hukum terhadap masyarakat hukum adat di Indonesia sebagai pemangku hak atas sumber daya genetik tersebut masih terhalang dengan sistem pengakuan bersyarat yang diterapkan Negara. Sistem pengakuan bersyarat terhadap masyarakat hukum adat telah menyebabkan terbatasnya masyarakat hukum adat yang diakui sebagai entitas hukum, sehingga terbatas pula masyarakat hukum adat yang diakui hukum sebagai pemangku hak atas sumber daya genetik.

b. Kebijakan Perlindungan Hukum terhadap Masyarakat Hukum Adat di Indonesia atas Pemanfaatan Sumber Daya Genetik di Masa Mendatang 1) Pembentukan UU Sui Generis atau HKI-Plus

\section{UU Sui Generis} seringkali dikaitkan dengan perlindungan terhadap pengetahuan tradisional. Hal ini dikarenakan substansi yang terpenting dari undang-undang sui generis yang dimaksud adalah adanya pengakuan yang tegas bahwa masyarakat lokal adalah 'pemilik' dari pengetahuan tradisional yang 


\begin{tabular}{|c|c|}
\hline bersangkutan. $^{22}$ UU sui & Rancangan \\
\hline generis tersebut dapat pula & Undang \\
\hline mengatur tentang hak & Perlindungan \\
\hline masyarakat hukum adat & Pemanfaatan \\
\hline dalam pemanfaatan sumber & Pengetahuan \\
\hline daya genetik secara tidak & Tradisional dan Ekspresi \\
\hline langsung, & Tradisional \\
\hline pengetahuan tradisional & (PTEBT) yang bertujuan \\
\hline memegang peranan penting & melindungi \\
\hline pengungkapan & pengetahuan \\
\hline manfaat dari sumber daya & baik yang berbasis seni \\
\hline genetik tertentu. Oleh & (artistic work) maupun \\
\hline karena itu, istilah yang & yang berbasis teknologi \\
\hline digunakan dalam CBD dan & (Bagian Menimbang huruf \\
\hline Protokol Nagoya adalah & c dan huruf d RUU \\
\hline "pengetahuan tradisional & PTEBT). RUU lainnya \\
\hline yang terkait dengan sumber & adalah RUU \\
\hline daya genetik." & Protokol \\
\hline Indonesia & bertujuan \\
\hline tahun 2007 telah memiliki & pengetahuan \\
\hline RUU Sui Generis yakni & tradisional \\
\hline 10, & dengan \\
\hline
\end{tabular}


Pengakuan

dan

Perlindungan Masyarakat

Adat yang mengatur secara

tegas keberadaan dan hak-

hak masyarakat adat juga

tengah digodok DPR.

RUU

PTEBT

tersebut masih memerlukan

revisi terkait tujuan dari

upaya pemberian

perlindungan, subjek yang

dilindungi, persyaratan atau

kriteria untuk mendapatkan

perlindungan, penyebutan

pengemban hak dan isi hak

secara tegas, cara

memperoleh hak atas

pengetahuan tradisional,

dan penegakan hukum atas

UU tersebut. RUU PTEBT

ini harus pula diimbangi

dengan

pengaturanpengaturan lain yang secara khusus

mengatur tentang sumber

daya genetik dan hak-hak

masyarakat hukum adat di

Indonesia. Oleh karena itu,

pengesahan RUU PTEBT

juga harus diikuti dengan

pengesahan RUU

Pengakuan dan

Perlindungan Masyarakat

Adat dan RUU Ratifikasi

Protokol Nagoya supaya

segala bentuk pemanfaatan

sumber daya genetik benar-

benar 'untuk sebesar-besar

kemakmuran rakyat'.

2) Rezim Access and Benefit Sharing (ABS)

Access and Benefit Sharing

(ABS) merupakan isu yang cukup

kuat dalam forum internasional

khususnya yang terkait dengan

sumber daya genetik. Isu ini 
sebenarnya telah diakomodasi

sepintas dalam CBD dan setelah

perundingan selama enam tahun

maka pada tanggal 29 September

2010 di Nagoya Jepang

disepakatilah The Nagoya Protocol

on Access to Genetic Resources

and the Fair and Equitable Sharing

of Benefits Arising from their

Utilization to the Convention on

Biological Diversity/ Protokol

Nagoya atau yang dikenal dengan

Protokol Nagoya. Protokol Nagoya

merupakan pelopor sebuah rezim

baru yang dapat mengimbangi

Rezim HKI yang selama ini lebih

menguntungkan negara-negara

maju yakni Rezim Access and

Benefit Sharing (ABS). Protokol

Nagoya adalah dasar hukum yang

kuat dalam memberikan kepastian

dan transparansi bagi negara

penyedia (provider) dan pengguna (user) sumber daya genetik.

Ketentuan dalam Protokol Nagoya

telah memberikan inovasi

perlindungan bagi negara penyedia

(provider) sumber daya genetik, yakni dengan adanya kewajiban bagi negara penyedia (provider)

dan pengguna

(user)

menandatangani suatu kontrak

kesepakatan bersama (mutual

agreed terms). Mutual Agreed

Terms tersebut akan berfungsi

sebagai suatu jaminan bagi negara

penyedia (provider) sumber daya

genetik ketika sumber daya genetik

miliknya diklaim sepihak oleh

pengguna (user).

Keberadaan Protokol

Nagoya turut 'memperkuat'

kedudukan masyarakat hukum adat

dalam mendapatkan keuntungan

atas komersialisasi pengetahuan,

inovasi, dan teknologi yang 
bersumber dari pengetahuan

tradisional berbasis sumber daya genetik milik mereka. Protokol

Nagoya ini dapat menjadi suatu harapan bagi negara-negara berkembang, termasuk Indonesia. ${ }^{23}$ sebagai negara (provider) sumber daya genetik dalam memperjuangkan pembagian keuntungan yang adil dan seimbang dengan pengguna (user). Protokol Nagoya dapat berjalan dengan efektif apabila ada kepedulian dari Pemerintah Republik Indonesia. Pemerintah Republik Indonesia dapat berperan

23 Indonesia telah menandatangani Protokol Nagoya pada tanggal 11 Mei 2011 bertepatan dengan acara Ministerial Segment of the 19th session of the United Nations Commission on Sustainable Development di Markas Besar PBB, New York. Saat ini proses ratifikasi Protokol Nagoya untuk menjadi Rancangan UndangUndang Pengesahan Protokol Nagoya sedang dilaksanakan. (Lihat: Dialog Interaktif Pengetahuan Tradisional Dalam Kerangka Protokol $<$ http://www.menlh.go.id/dialog-interaktifpengetahuantradisional-dalam-kerangkaprotokol-nagoya/>, diakses pada 1 Oktober 2012. sebagai 'wakil' dari masyarakat

hukum adat untuk membuat kebijakan pengaturan akses atas sumber daya genetik. Setiap akses terhadap pengetahuan tradisional yang terkait sumber daya genetik harus diawali dengan PADIA (Persetujuan Atas Dasar Informasi Awal) atau Prior Informed Consent (PIC). ${ }^{24}$ yang prinsip-prinsipnya harus dihormati user bila melakukan akses atas sumber daya genetik. Pemerintah baik Pemerintah Daerah dan Pemerintah Pusat juga dapat berperan sebagai custodian dalam mekanisme Benefit Sharing. ${ }^{25}$ ini dengan berperan dalam mempersiapkan

PADIA / PIC adalah pemberitahuan dari pemohon akses kepada penyedia Pengetahuan Tradisional yang Terkait Sumber Daya Genetik tentang semua informasi dalam rangka kegiatan akses yang dipergunakan oleh penyedia sebagai bahan pertimbangan dalam memberikan persetujuan akses terhadap Sumber Daya Genetik yang dimilikinya. (Lihat Kertas Posisi Kementerian Lingkungan Hidup, Op.Cit., hlm 19).

${ }^{25}$ Agus Sardjono, Op.Cit., hlm. 321 
format Mutual Agreed Terms $(\mathrm{MTA}){ }^{26}$ yang memperhatikan hak-hak masyarakat hukum adat pada khususnya, hak-hak warganegara Indonesia pada umumnya.

\section{E. Simpulan}

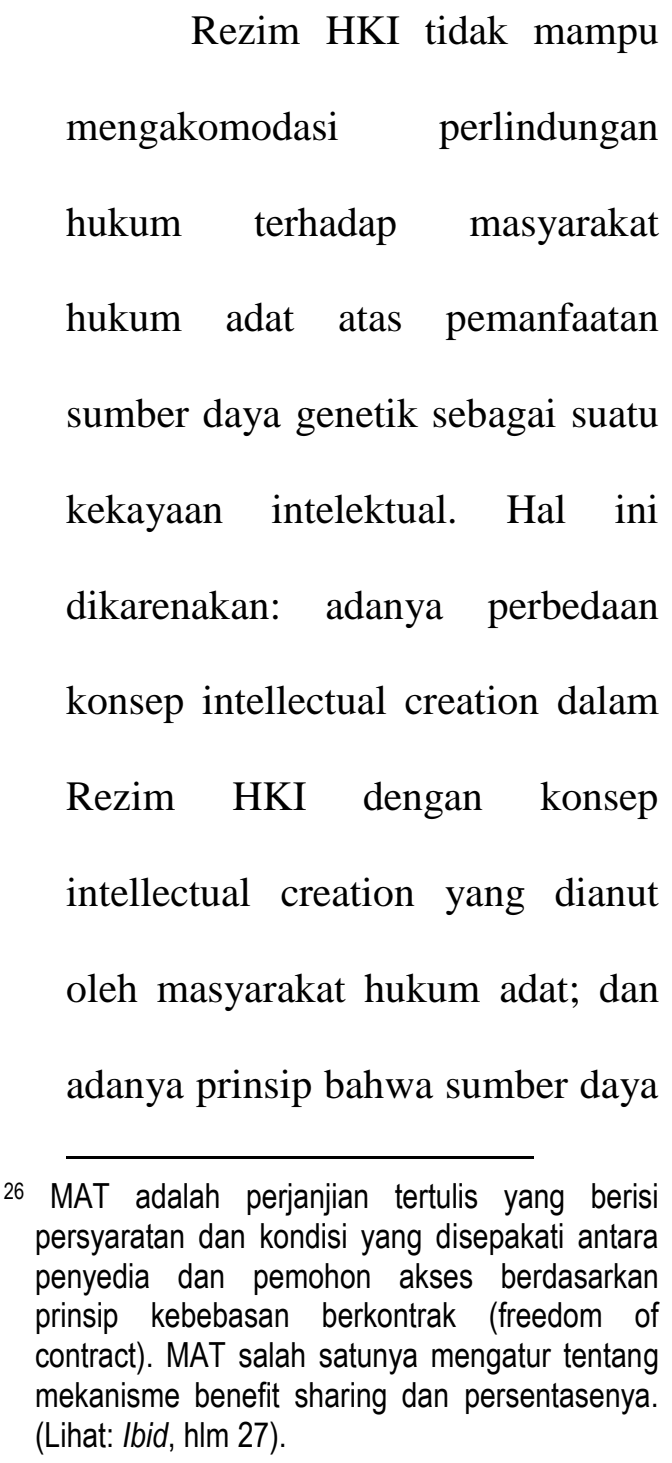

genetik merupakan warisan bersama umat manusia di satu sisi memberikan manfaat yang seluasluasnya bagi semua pihak tanpa kecuali untuk mengeksplotasinya. Kebijakan perlindungan hukum terhadap masyarakat hukum adat di Indonesia atas pemanfaatan sumber daya genetik sebagai suatu kekayaan intelektual di masa kini, yaitu adanya sistem pengakuan bersyarat yang diterapkan untuk kelompok masyarakat adat supaya dapat diakui sebagai masyarakat hukum adat, dan perlindungan hukum terhadap masyarakat hukum adat di Indonesia dalam kaitannya dengan sumber daya genetik meliputi hak atas wilayah tempat tinggalnya dan hak hidup dan mencari penghidupan di wilayah tempat tinggalnya. Hakhak masyarakat hukum adat ini 
mewajibkan pihak luar yang mengeksploitasi sumber daya genetik yang ada di wilayah hidup masyarakat hukum adat untuk menghormati kearifan lokal mereka.

$$
\text { Berdasarkan hal tersebut, }
$$

maka kebijakan di masa mendatang dapat dibentuk perundang-undangan sui generis yang disesuaikan dengan karakteristik masyarakat hukum adat di Indonesia, serta Implementasi Rezim Access and Benefit Sharing $(\mathrm{ABS})$ sebagaimana diatur dalam Protokol Nagoya yang mewajibkan setiap user harus mempunyai PADIA/Prior Informed Consent (PIC) sebelum melakukan akses terhadap sumber daya genetik di wilayah tertentu dan dalam eksploitasi sumber daya genetik harus berdasarkan Mutual Agreed Terms (MTA) yang mengatur kesepakatan bersama antara user dan provider dalam mekanisme benefit sharing, sehingga Pemerintah Indonesia diharapkan segara meratifikasi Protokol Nagoya serta mensahkan RUU Pengakuan dan Perlindungan Hak Masyarakat Hukum Adat.

\section{Daftar Pustaka}

Agus Sardjono, 2006, Hak Kekayaan Intelektual dan Pengetahuan Tradisional. Bandung: PT. Alumni.

Johannes Muller. 2006. Perkembangan Masyarakat Lintas Ilmu. Jakarta : PT. Gramedia Pustaka Utama.

Khudzaifah Dimyati. 2004. Teorisasi Hukum: Studi tentang Perkembangan Pemikiran Hukum di Indonesia 1945-1990. Surakarta : Universitas Muhammadiyah Surakarta Press.

Maria Soemardjono, 2009, Tanah dalam Perspektif Hak Ekonomi, Sosial, dan Budaya, Jakarta, Kompas Gramedia

Mukti Fajar dan Yulianto Achmad. 2010. Dualisme Penelitian 
Hukum Normatif dan Empiris. Yogyakarta : Pustaka Pelajar.

Otje Salman \& Anton F. Susanto, 2004, Beberapa Aspek Sosiologi Hukum, Bandung, PT. Alumni

Peter Johan Schei dan Morten Walloe Tvedt, Genetic Resources in the CBD: the Wording, the Past, the Present, and the Future

Rikardo Simarmata, 2006, Pengakuan Hukum Terhadap Masyarakat Adat di Indonesia, Bangkok: UNDP

Soerjono Soekanto. 2010. Pengantar Penelitian Hukum. Jakarta: Penerbit Universitas Indonesia (UIPress).

Tim Lindsey. 2005. Hak Kekayaan Intelektual: Suatu Pengantar. Bandung: Alumni.

\section{Jurnal/Majalah:}

FX Adji Samekto dan Paramita Prananingtyas, Keberpihakan Konvensi Keanekaragaman Hayati pada Kepentingan Negara Maju, Majalah MasalahMasalah FH Univesitas Diponegoro, Vol. 35 No. 2 AprilJuni 2006).

\section{Website:}

Sebastian Oberthur, dkk. 2011. Study Intellectual Property Rights on Genetic Resources and TheFight Against Poverty. Belgia: Eurepean Parliament, http://www.ecologic.eu/files/atta
chments/Projects/2610/2610_20_ ipr_study_final.pdf

Dialog Interaktif Pengetahuan Tradisional Dalam Kerangka Protokol Nagoya, 2009, <http://www.menlh.go.id/dialoginteraktif-pengetahuantradisional-dalam-kerangkaprotokolnagoya/IWGIA The Indigenous World>.

$<$ Tanpa Nama>, <Tanpa Judul>, $<$ http://www.aman.or.id/wpconte nt/plugins/downloadsmanager/up load/THE\%20INDIGENOUS\%2 0WORLD-2009\%20Indo.pdf> 